\title{
Impact of Job Characteristics on Employees Emotions \& Work-Related Outcomes in Pakistan
}

\author{
Iffat S. Chaudhry ${ }^{1}$, Jean G. Maurice ${ }^{1} \&$ Mohamed Haneefuddin ${ }^{1}$ \\ ${ }^{1}$ College of Business Administration, A'Sharqiyah University, Ibra, Sultanate of Oman \\ Correspondence: Iffat S. Chaudhry, College of Business Administration, A'Sharqiyah University, Ibra 400, \\ Sultanate of Oman. Tel: 96-8-9972-7336. E-mail: ch.iffat@yahoo.com
}

Received: May 4, 2015

doi:10.5539/ijbm.v10n8p233

\author{
Accepted: July 9, 2015 \\ Online Published: July 22, 2015 \\ URL: http://dx.doi.org/10.5539/ijbm.v10n8p233
}

\begin{abstract}
The impact of job characteristics on organizational success and its members' work attitudes and behaviors is not new in the field of organizational behavior. However, the empirical work on gauging the influence of job features on affective states of employees and its subsequent impact on work outcomes is rather marginal. The study intends to validate the relationship amid job characteristics, employees' affective states and their attitudes and behaviors.

The five core job dimensions of Job Characteristics Model i.e. skill variety, task identity, task significance, autonomy and feedback have been adopted to determine the characteristics of the job undertaken. Affective Events Theory has been used to examine the hypothesized relationships between the antecedent (i.e. job characteristics) and consequents of affective experiences (i.e. attitudes: job satisfaction, commitment to organization; and behaviors: organizational citizenship behavior and counterproductive work behavior) of the employees while at work.

Regression analysis of the survey data from 215 organizational members from private and public organizations in Pakistan, identified the significant impact of job autonomy, skill variety and task significance on the affective states of employees impacting their satisfaction level towards the job. However, the emotional experiences due to job characteristics showed no influence on employee's commitment towards the organization as well their citizenship and counterproductive work behavior.
\end{abstract}

Keywords: job characteristics, emotions, Pakistan, work attitudes, work behaviors

\section{Introduction}

Prior literature suggests that emotionally intelligent organizations are capable of leveraging the abilities of their human capital to confront the competition in knowledge based world economy more effectively (Jacobs, 2001), legitimizing the innate role of emotions in organizational performance (Zebre, Hartel, \& Ashkanasy, 2006). Both psychological and organizational studies (LeDoux, 1998; Isen, 2000) support that affective dispositions and experiences explain distinction in work attitudes and behaviors (Judge \& Kammeyer-Mueller, 2008), thus, making it imperative in comprehending the workforce attitudes and behaviors (Ashforth \& Humphrey, 1995). However, despite the significant role of work features in organizational success and individual well-being (Jelstad, 2005), its impact on the affective states and consequent behaviors of employees is still unexplored (Burke et al., 1989).

In prior researches support the direct as well as indirect influence of job characteristics on personal and work outcomes (Renn \& Vandenberg, 1995). The researchers either tested its influence on employees affect (Saavedra \& Kwun, 2000) or the impact of work characteristics on work-outcomes (Jelstad, 2005) but the empirical investigation to determine the holistic view of the impact of job characteristics on affective states and subsequent affective-driven attitudes and behaviors is still missing. Therefore, the present paper intends to examine the impact of job characteristics on employees' emotions, and the subsequently how these affective experiences influence on their work related attitudes and behaviors.

The study proposes that the characteristics of the assigned job have a significant influence on the affective states of employees which, in turn, shape their work related outcomes i.e. job satisfaction, commitment to organization, citizenship behavior and counterproductive work behavior. 


\subsection{Objectives and Contributions of the Study}

First of all, the direct impact of job characteristics on the affective state of employees shall be investigated using Job Characteristics Model (JCM). Later, the study examines the subsequent influence of the employee's affective experiences on their work-related outcomes i.e. attitude and behaviors within the organization using Affective Events Theory (AET). The measures of job satisfaction and organizational commitment shall determine the employee's attitude, whereas the constructs of organizational citizenship behavior and counterproductive behavior will measure employees' behavior within the organization. Up to researcher's knowledge, the meta-analysis of the impact of job characteristics on workforce affective experiences, and its subsequent influence on their attitudes and behaviors is new in its kind in an Asian working environment, thus, adding novelty by fulfilling the existing gap in knowledge domain.

\section{Literature Review}

The job characteristics model by Hackman and Oldham (1975) is based on the perception that task itself plays a key role in regulating employees' motivation, as a monotonous job might reduce it but a challenging job might enhance it further. JCM determines five core job dimensions, i.e. skill variety, task identity, task significance, autonomy and feedback, which impact on the affective experiences of employees during work. Skill variety is 'a degree to which a job requires variety of skills and talents of the employee'; task identity refers to 'the job requiring completion of identifiable piece of work'; task significance indicates 'the impact of job on lives and work of other people'; autonomy is 'the freedom given to the worker in determining the way of task accomplishment'; feedback refers to 'the information given to worker pertaining to his performance as a result of carrying out his tasks'.

JCM is most widely recognized tool for identifying the work context (Garg \& Rastogi, 2006). Also it has been used by researchers to determine the influence of task perception on employee's work-related outcomes (Spector \& Jex, 1991). Thus, it has been selected for analyzing the impact of work characteristics on employees' emotions, informing their attitudes and behaviors within organizational settings in the current study.

\subsection{Job Characteristics, Emotions and Employees Attitudes and Behaviors}

The relationship of job characteristics with affective response have been well documented in several classical researches (Dunham, 1979; Cummings \& Burger, 1976). Jonge and his colleagues (2001) found an empirical support for the impact of job characteristics on psychological well-beings of the workers in their two-wave panel study of health care professionals. Job characteristics also hold a primary influence on the performance of the employees by enhancing their satisfaction, commitment and work behaviors. Sokoya (2000) testified that job characteristics along with personal traits regulate the level of job satisfaction. Likewise, James and Tetrick (1986) established that job characteristics are the concrete motive for job satisfaction. Also, Adler (1991) reinforced that the employees with positive perceptions of skill variety, task significance, autonomy and feedback reported higher levels of satisfaction. Similarly, Bassey (2002) recognized that job characteristics are significant for motivating employees in the organization. Also, Judge, Erez and Bono (1998) reported in their study that job characteristics mediated the relationship between core self-evaluation and job satisfaction. Therefore, the hypothesis developed to test the variable under discussion is as follows:

\section{Hypothesis 1: Job Characteristics hold significant influence on workforce emotions.}

Prior research indicates the increasing trend of investigating the role of emotions in workplaces (Bolton, 2000; Hochschild, 1979, 1983), which has been shaped up as one of the major area of focus for management in $21^{\text {st }}$ century (Ashkanasy \& Daus, 2002). Emotions have been increasingly recognized as a natural part of the organizational life (Fisher \& Ashkanasy, 2000) and work role (Gibson, 2006) influencing attitudes and behaviors of its members (Weiss \& Cropanzano, 1996; Fisher, 1998; Cote \& Morgan, 2002).

Workforce emotions are well-taken into consideration as integral to the understanding of their attitudes and behaviors towards work and organization as a whole (Zerbe, Hartel, \& Ashkanasy, 2006). Individual's emotions have been claimed as a strong predictor of his/her behaviors (Weiss \& Cropanzano, 1996). Lazarus (1991) specified that "when people are reacting to the emotions, coping with it becomes the priority which takes precedence over other behaviors" (Weiss \& Cropanzano, 1996). Several studies have confirmed the connection of employee's emotions with the customer services, leader-follower relations, work ethics, change management and so on (George, 1990; Fineman, 1993; Ashforth \& Humphrey, 1995). Similarly, Estrada, Isen, and Young (1994) identified that positive affect increases the level of intrinsic motivation; on the other hand, negative emotions result in low expectations and less-effective performance. Grandy, Tam, and Brauberger (2002) confirmed that negative emotions in response to work features may result in withdrawal behaviors ultimately 
leading to the higher intention of leaving the job.

The researchers have been progressively discovering the role of people's emotions in guiding the development of their attitudes and the behaviors at work (e.g. Ashkanasy, 2003; Weiss, 2002). The study framework includes the assessment of the employees' attitudes (job satisfaction and organizational commitment) and behaviors (organizational citizenship and counterproductive work behavior) in response to the variety of emotions experienced due to the work features.

\subsubsection{Work-Attitudes}

Locke (1976, p. 1304) defined job satisfaction as "a pleasurable or positive emotional state resulting from the appraisal of one's job or job experiences". Brief and Weiss (2002, p. 284) stated, "relationships between negative and/or positive affectivity and job satisfaction now are commonplace in the literature". Most of the emotion-centric researches have supported strong association between one's emotional characteristics and job satisfaction (Watson \& Slack, 1993). Likewise, a comprehensive view of 27 articles by Connolly and Viswesvaran (2000) recognized that impact of positive and negative affectivity on satisfaction with job. Agho, Price, and Mueller (1992) reported in their study a significant positive correlation of positive affect and negative affect with job satisfaction ( $p=.01$, and $p=.01$, respectively). Prior investigations confirmed that the individuals vary in their job satisfaction level based on their mood and emotional experiences (Fisher, 2002). Based on the empirical evidences mentioned above, following hypothesis will be tested:

\section{Hypothesis 2: Workforce emotions hold significant influence on job satisfaction.}

Along with job satisfaction, organizational commitment (OC) is also held as a significant contributor to employee's performance at the workplace. OC is defined by Mowday and colleagues (1979) as "an identification with the goal's and values of the organization, a desire to belong to the organization and a willingness to display effort on behalf of the organization" (Michael, 1998, p. 319). The type of commitment one has with the organization might be: normative, continuance, affective, identification or values-based, due to which he/she opts to keep working in the same workplace.

Rhoades, Eisenberger, and Armeli (2001) stated that job contextual factors like supervisor's support, performance assessment criteria and reward distribution, and perceived organizational justice specific to procedures play prominent part in developing employee's long-term commitment with the organization. The emotions felt due to organization's management and its policies lay foundation to employee's decision of maintaining the organizational membership. The prior findings support that emotional experiences in organizations create the solid link between workforce daily work experiences and their commitment to organization (Klinger, Barta, \& Maxeiner, 1980; Klinger, 1977). Li, Ahlstrom and Ashkanasy (2010) in their multi-level study confirmed the association between the feelings of guilt/determination and the commitment with workplace. Therefore, organizational commitment has been included as a determinant of performance to measure the influence of emotions on employees' affective commitment towards organization.

\section{Hypothesis 3: Workforce emotions hold significant influence on organizational commitment.}

\subsubsection{Work-Behaviors}

Employee's behavior influences directly on the organizational performance (Podsakoff \& MacKenzie, 1997). Organizational Citizenship Behavior (OCB) is described often as extra-role behavior (not included in the formal job responsibilities of the employee) benefitting other employees and organization (Van Dyne et al., 1995; Organ, 1988). It serves as a behavioral cue of individual's commitment to organizational success (Podsakoff et al., 2009; p. 124).

Lee and Allen (2002) proposed that positive mood is central to organizational citizenship behaviors like giving constructive suggestions, protecting organization, spreading goodwill and developing own self. Forgas (1999) stated that "positive moods generate a more optimistic, cooperative, and confident approach to interpersonal tasks, while negative moods promote a more pessimistic, competitive, and antagonistic approach". George (1991) reported in his study on retail organizations that the sales personnel who experienced positive emotions at work were more spontaneous and helpful toward their co-workers. Likewise, Carlson, Charlin, and Miller (1988) asserted that positive emotions promote helping attitude towards others.

However, William and Anderson (1991) affirmed that OCB needs to be determined at two different levels, i.e., individual (OCB-I) and organizational (OCB-O). OCB-I strand measures the employee's behavior oriented towards other organizational members e.g. sharing the workload of others etc. OCB-O accounts the employee's behavior towards the organization, e.g., spreading goodwill. Therefore, the impact of employees' emotional experiences on their citizenship behavior-towards individuals as well as organization-was tested separately (see 
McNeely \& Meglino, 1994).

Hypothesis 4a: Workforce emotions hold significant influence on organizational citizenship behavior towards individuals $(O C B-I)$.

Hypothesis 4b: Workforce emotions hold significant influence on organizational citizenship behavior towards organization as a whole $(O C B-O)$.

Contrary to OCB, counterproductive work behavior (CWB) is one of the biggest challenges confronted to the organizations (Chappell \& Di Martino, 2006). CWB refers to "volitional acts that harm or intends to harm organizations or people in organizations" (Yang \& Diefendorff, 2009, p. 260). They are wide-spread in the organization. The prior investigations have revealed that workforce negative emotions form the bases for the adoption of counterproductive behaviors (Spector \& Fox, 2005). Spector and colleagues (2006) reported in their study that the negative emotionality mediates-fully as well as partially- the correlation amid counterproductive behaviors and job stressors, fully as well as partially. Likewise, evidence from another study suggested that the negative emotions experienced in response to undesirable occurring hamper the interpersonal co-ordination as well as job performance (Bagozzi, 2003).

Therefore, along with citizenship behavior, the study also assessed the impact of emotional experiences on counterproductive behaviors of employees. Robinson and Bennett (1995) suggested two different aspects of CWB i.e. interpersonal and organizational; where interpersonal level (CWB-I) strand determines the behaviors of an employee towards other organizational members e.g. spreading rumor; and organizational level (CWB-O) considers the behaviors of an employee towards the organization as a whole, e.g. wasting time by taking long breaks. The study took both the individual and the organizational level counterproductive behaviors into considerations and the hypotheses developed for testing are:

Hypothesis 5a: Workforce emotions hold significant influence on interpersonal counterproductive work behavior (CWB-I).

Hypothesis 5b: Workforce emotions hold significant influence on organizational counterproductive work behavior (CWB-O).

The theoretical framework delineating the causal relationship between the study variables (job characteristics, affective experiences and work-related outcomes) on the basis of prior knowledge and hypothesized model for testing these relationships are as under.

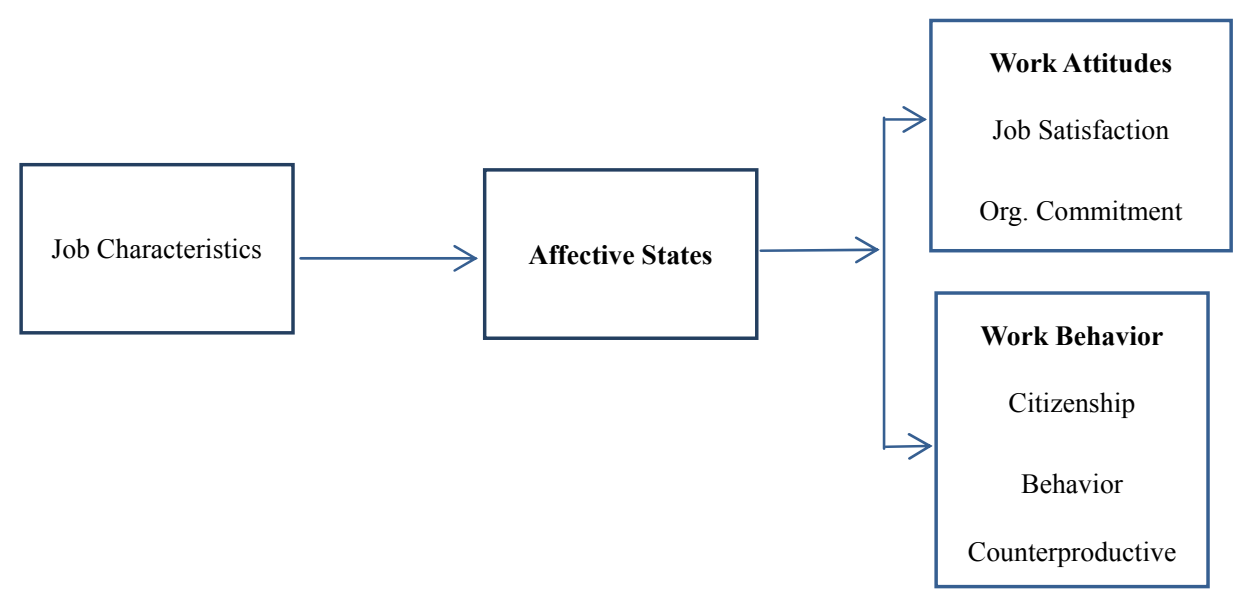

Figure 1. Theoretical framework 


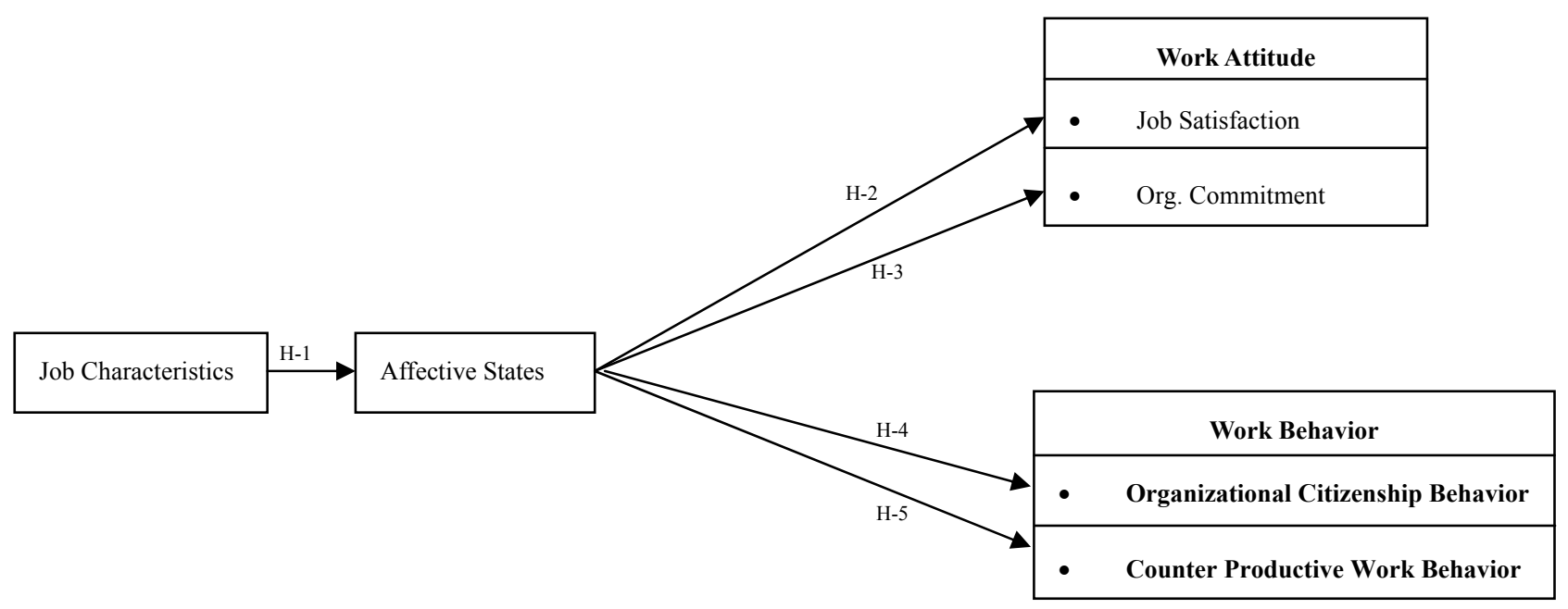

Figure 2. Hypothesized relationship of study variables

\section{Method}

A survey was conducted to collect the data for testing the hypothesized relationships amongst the study variables. The measures adopted, sample selection and data collection methods have been discussed below:

\subsection{Measures}

The items included in the questionnaire for measuring the influence on job characteristics on workforce emotions and its subsequent impact on job satisfaction, commitment to organization, organizational citizenship and counterproductive work behavior are as follows:

The five items used for measuring job characteristics construct were adapted from Lawrence (2001). The items were reworded to make them simple and easy to understand. The Likert-type scale used five points $(1=$ Little, $3=$ Moderately, $5=$ Very Much) to objectively describe the job.

The discrete measures used to evaluate the affect experienced by employees in response to the job characteristics were 'positive', 'negative' and 'neutral'.

The three item scale was used to measure job satisfaction construct. The items were adapted from the 5 item scale used by Judge et al. (1998). The items were measured on five points scale ranging from strongly disagree (1) to strongly agree (5).

The two items scale was used to assess the employees' affective and overall commitment with the organization due to the constraint of questionnaire length. They were measured on five point (1 'Strongly Dis Agree' to 5 'Strongly Agree') Likert-scale.

The scale originally developed by Lee and Allen (2002) was adapted for the measurement of two OCB dimensions. On 7-items scale, organizational citizenship behavior (OCB) was measured on two different dimensions i.e. behavior towards other individuals (OCB-I) and the organization (OCB-O) separately. Five point scale $($ Never $=1$, Sometimes $=3$, Always $=5$ ) was adopted.

6 items scale of five points (Never $=1$, Sometimes $=3$, Always $=5$ ) was used to measure counterproductive work behavior (CWB) from the two different dimensions of interpersonal (CWB-I) and organizational (CWB-O). 2 items, i.e., 'I had been nasty or rude to a client or customer' and 'I started or continued a damaging or harmful rumor at work' were adapted from Spector et al. (2006).

\subsection{Sample}

Pakistan Employees from both public and private sector organizations were selected randomly using professional network (LinkedIn) for conducting survey by using self-administered questionnaire. Organizations performing in wide-set of industries, i.e. banks, electronic and print media, telecom sector, textile manufacturers, research organization, hotels, consumer goods manufacturers, financing companies, universities, automobiles and teaching hospitals, were included to confirm the diverse representation of workforce suitable for generalizing the results. Questionnaires were administered by hand and online amongst five hundred employees from wide-ranging business types working in the major two cities of Pakistan, i.e. Islamabad and Lahore. 


\subsection{Data Collection}

In total five hundred questionnaires were distributed amongst the public and private sector work force of Pakistan, both by hand as well as by using online service.

The personalized emails were sent to the employees with the information regarding the survey and the request was made for their participation in it. On the confirmation of participation from two hundred and sixty seven employees, the online questionnaire link was forwarded to one hundred and eighty five participants, along with the guidelines for the online filling of the questionnaire. Eighty two questionnaires were distributed by hand amongst the employees from organizations based in Islamabad.

The reminders were given on the regular interval of one week to resolve the queries (if any) of the respondents, facilitating the completion of the questionnaire. The average time consumed in the collection of filled questionnaires was three weeks.

The total responses received from the questionnaires, administered both by hand and online, were two hundred and fifteen with the average response rate of $80.5 \%$. The high response rate can be attributed to the respondents' prior confirmation of participating in the survey. The respondent represented the workforce from thirty nine (39) different companies, giving a wide representation of workforce from two main business hubs in Pakistan.

The initial filtration of questionnaires with high missing values reduced the data size from 215 cases to 177 . The data sets available for the analyses were entered using SPSS (Statistical Package for Social Science).

\section{Results \& Discussion}

Prior to hypotheses testing, the validity and reliability checks were undertaken to confirm the error free measurement scales (section 4.1). Subsequently, descriptive analysis (section 4.2) was undertaken, leading to hypotheses testing and discussion of findings (section 4.3).

\subsection{Validity and Reliability Checks}

An exploratory factor analysis was conducted using principal component analysis with the help of IBM SPSS application to assess the factor structure and individual items validity (Costello \& Osborne, 2005). The results pertaining to all the constructs and corresponding items met the minimum threshold specified for meeting the quality criteria. The communalities of all the indicators remained high with values greater than 0.50 . Next, Cronbach alpha was used for assessing scales reliability (Pallant, 2001). According to the guideline of Nunnally (1978) the Cronbach's alpha for the scale underlying test must be equal to or higher than 0.70 to pass the test of reliability. The alpha values of all the constructs met the reliability criteria of 0.70 except for organizational commitment scale, which remained low compared to minimum threshold but the most obvious reason was the less number of indicators for its measurement (to curtail the length of questionnaire). However, the questions measured the overall commitment level of the employees due to which the construct was kept for hypotheses testing. The overall validity and reliability test results confirmed the error free measurement models developed for the constructs. The results have not been included in the paper but available upon request.

\subsection{Descriptive Analysis}

The descriptive details of all the summed items were calculated for the descriptive analyses of the study variables and their sub dimensions (Table 1). The mean value of all the study variables (i.e. job satisfaction, job characteristics, organizational commitment, and organizational citizenship behaviors) was higher than 3.5 (5 range). However, the mean value of counterproductive work behaviors (I \& O) was not higher than 1.78 with standard deviation $=.727$, depicting low tendency of the work force towards counterproductive work behaviors. 
Table 1. Means \& standard deviation of study variables

\begin{tabular}{lcc}
\hline VARIABLE & MEAN & ST. DEVIATION \\
\hline Job Characteristics (Overall) & 3.68 & 1.156 \\
a. Working Closely with Others & 3.92 & 1.105 \\
$b . \quad$ Job Autonomy & 3.51 & 1.124 \\
$c . \quad$ Task Identity & 3.80 & 1.073 \\
$d \quad \quad$ Skills Variety & 3.46 & 1.283 \\
e. Task Significance & 3.73 & 1.198 \\
Job Satisfaction & 3.45 & 1.079 \\
Organizational Commitment & 3.66 & 1.094 \\
Organizational Citizenship Behavior (Overall) & 3.76 & 1.049 \\
Organizational Citizenship Behavior-Individual & 3.83 & 1.037 \\
Organizational Citizenship Behavior-Organizational & 3.70 & 1.062 \\
Counterproductive Work Behavior (Overall) & 1.72 & 0.727 \\
Counterproductive Work Behavior-Interpersonal & 1.82 & 0.731 \\
\hline
\end{tabular}

\subsection{Hypotheses Testing and Findings}

The series of tests using linear regression method were performed to test the stated hypotheses (results given in table 3). A significant and positive relationship was found between the job characteristics and the affective states of the employees with $r=.509$ and $p$-value $<0.01$. The task autonomy, skills variety and task significance dimensions of the job characteristics showed significant positive relationship with emotional experiences of employees with $p$-values $=.000, .006$ and .033 respectively (Table 2). However, chance of working closely with others and job identity showed no significant impact on affective experiences of the workforce. Thus, hypothesis 1 accepted.

Table 2. Summary of test results of hypothesis 1

\begin{tabular}{|c|c|c|c|c|c|}
\hline \multirow[t]{2}{*}{ Job Characteristics } & \multicolumn{5}{|c|}{ Results on Affective States } \\
\hline & $B$ & S.E. & Beta & $T$ & PValue \\
\hline 1. Working Closely with Others & .036 & .067 & .040 & .534 & $p=.594$ \\
\hline 2. Job Autonomy & .271 & .065 & .304 & 4.166 & $* * * p=.000$ \\
\hline 3. Task Identity & .032 & .069 & .034 & .461 & $p=645$ \\
\hline 4. Skills Variety & .158 & .057 & .203 & 2.790 & $* * p=.006$ \\
\hline 5. Task Significance & .129 & .060 & .154 & 2.148 & $* p=.033$ \\
\hline
\end{tabular}

$* * *$ significant at the level $0.001 * *$ significant at the level $0.01 *$ significant at the level 0.05

The results showed a strong positive relationship between affective experiences and job satisfaction with $r=.208$ and $p$-value $<0.01$; validating hypothesis 2 .

The employees affective experiences due to job characteristics demonstrated no relationship with organizational commitment of the employees with $r=.074$ and $p$-value $=.325$; thus, rejecting hypothesis 3 .

Likewise, the affective experiences of employees showed no significant relationship with organizational citizenship behavior w.r.t. individual as well as organization as a whole (with $r=.024$ and .115 and $p$-value $=.754$ and .129 respectively). Therefore, hypothesis $4 \mathrm{a}$ and $4 \mathrm{~b}$ were rejected.

Similarly, employees' emotions experienced due to job characteristics showed no significant relationship with their counterproductive work behaviors i.e. interpersonal as well as organization specific. The values of $r$ and $p$ found for the individual and organizational specific counterproductive work behaviors were .029 and .091 and .699 and .226 respectively. Thus, hypothesis $5 \mathrm{a}$ and $5 \mathrm{~b}$ were rejected as well. 
Table 3. Summary of hypotheses test results

\begin{tabular}{|c|c|c|c|}
\hline \multirow[t]{2}{*}{ Study Hypoteses } & \multicolumn{3}{|c|}{ RESULTS } \\
\hline & Acceptance/Rejection & $\mathbf{R}$ & P Value \\
\hline Hypothesis 1 & ACCEPTED & .509 & $* * * p=.000$ \\
\hline Hypothesis 2 & ACCEPTED & .208 & $* * p=.006$ \\
\hline Hypothesis 3 & REJECTED & .024 & $p=.754$ \\
\hline Hypothesis 4a & REJECTED & .223 & $p=.186$ \\
\hline Hypothesis $4 \mathrm{~b}$ & REJECTED & .115 & $p=.129$ \\
\hline Hypothesis5a & REJECTED & .029 & $p=.699$ \\
\hline Hypothesis $5 b$ & REJECTED & .091 & $p=.226$ \\
\hline
\end{tabular}

***significant at the level $0.001 * *$ significant at the level $0.01 *$ significant at the level 0.05 .

The study identified a significant and positive relationship between job characteristics and affective experiences of the employees $(p=.000)$. Specifically, the work features like autonomy to take decisions on their own related to their task accomplishments instead of coursing back to manager generated positive emotions amongst the employees $(p=.000)$. Likewise, people experienced positive emotions by using the variety of their skills for performing daily tasks $(p=.006)$. Similarly, when employees perceived their tasks as important piece of work, they felt positive emotions $(p=.03)$. The positive relationship of job autonomy and task significance with positive emotions supported the results of the study conducted by Saavedra and Kwun (2000). However, the findings did not suggest the influence of task identity and working closely with the people on the affective experiences of the employees.

The findings supported the prior research by recognizing the positive significant relationship between job characteristics and employees' satisfaction towards job $(p=.006)$. The people who are given chance to perform significant tasks using variety of skills and take decisions on their own for its accomplishment tend to have higher level of job satisfaction.

However, against the study expectations no influence of employees' affective experiences was found on employees' overall commitment to organization. Likewise, emotions also showed no impact on employees' citizenship and counterproductive work behaviors, towards individuals as well as the organization as a whole. The unexpected study outcomes may be attributed to high rate of unemployment in Pakistan, due to which prefer to stay within the organization based on continuance commitment. Also, the tendency of fewer counterproductive behaviors and more citizenship behaviors may be due to high explicit control measures opted by the firms in Pakistan corporate sector. However, these areas further need to be investigated by future researchers to assess why negative emotional experiences at Pakistani workplaces did not influence on the commitment, citizenship and withdrawal behaviors of the employees.

\section{Conclusion}

Job Characteristics Model (JCM) by Hackman and Oldham was adopted by the researcher for determining the features of the work allocated to the employees and its effect on their emotions was measured on a classical scale of positive, negative and neutral. The workforce attitudes and behaviors were measured in terms of their: organizational commitment, job satisfaction, counterproductive and citizenship behaviors.

The findings confirmed the positive relationship between job characteristics and workforce emotions. Autonomy given, variety of skills used and the significance of task assigned to the employees had a significant influence on their affective experiences. Likewise, the subsequent influence of these affective experiences was found positive only with respect to the level of employees' satisfaction with the job. Nevertheless, the study findings did not confirm the influence of negative or positive emotional experiences of employees on their citizenship and withdrawal behaviors, which was against the expectations of study hypotheses. However, job satisfaction may have strong impact on work performance, making it crucial for the management to design the work in such a way which could facilitate the autonomy to take decisions related to responsibility assigned along with the chance of utilizing the optimum skills held by them and must be perceived as significant as well, in order, to increase the level of performance.

The study is however, subject to some limitations. The findings of the study confirming no effect of employees' emotional experiences on employees' organizational commitment, their citizenship and counterproductive work behavior cannot be generalized at the global level due to the high unemployment rate in Pakistan with fewer options for switching jobs. Another limitation is that though job characteristics model is used frequently for 
determining the work features, however, it may not be claimed that these five factors completely determine the characteristics on the assigned job. Instead, there might be several other factors which have not been taken into consideration in this study. This gap needs to be filled by future studies.

Despite the stated limitations, the study contributed to the literature being the pioneer study in giving a holistic view of the effect of job characteristics on workforce emotions and their emotional reactions in the form of their attitudes and behaviors within the public and private organizations of the developing country with several economic issues. It is hoped that this research will contribute to the understanding of affective work features of academicians as well as researchers.

\section{References}

Adler, N. (1991). International Dimensions of Organizational Behavior (2nd ed.). PWS-Kent, Boston, MA.

Agho, A., Price, J., \& Mueller, C. (1992). Discriminant validity of measures of job satisfaction, positive affectivity and negative affectivity. Journal of Occupational \& Organizational Psychology, 65(3), 185-196. http://dx.doi.org/10.1111/j.2044-8325.1992.tb00496.x

Ashforth, B., \& Humphrey, R. (1995). Emotion in the workplace: a reappraisal. Human Relations, 48(2), 97-125. http://dx.doi.org/10.1177/001872679504800201

Ashkanasy, N. (2003). Emotions in organizations: A multilevel perspective. In F. Dansereau, \& F. Yammarino (Eds.), Research in multi-level issues: Multi-level issues in organizational behavior and strategy (Vol. 2, pp. 9-54). Oxford, UK: Elsevier Science.

Ashkanasy, N., \& Daus, C. (2002). Emotion in the workplace: The new challenge for managers. Academy of Management Executive, 16(1), 76-86. http://dx.doi.org/10.5465/AME.2002.6640191

Bagozzi, R. (2003). Positive and negative emotions in organizations. In K. Cameron, J. Dutton, \& R. Quinn (Eds.), Positive organizational scholarship: Foundations of a new discipline (pp. 176-409). San Francisco: Berrett-Koehler.

Bassey, M. (2002). Motivation and work: Investigation and analysis of motivational factors at work. Retrieved from http://www.ep.liu.se/exjobb/eki/2002/fek/009

Bolton, S. (2000). Emotions here, emotions there, emotional organizations everywhere. Critical Perspectives on Accounting, 11(2), 115-171. http://dx.doi.org/10.1006/cpac.1998.0236

Brief, A., \& Weiss, H. (2002). Organizational behavior: Affect in the workplace. Annual Review of Psychology, 53, 279-307. http://dx.doi.org/10.1146/annurev.psych.53.100901.135156

Burke, M., Brief, A., George, J., Roberson, L., \& Webster, J. (1989). Measuring affect at work: Confirmatory analysis of competing mood structures with conceptual linkage to cortical regulatory systems. Journal of Personality and Social Psychology, 57, 1091-1102. http://dx.doi.org/10.1037/0022-3514.57.6.1091

Carlson, M., Charlin, V., \& Miller, N. (1988). Positive mood and helping behavior: A test of six hypotheses. $\begin{array}{lllll}\text { Journal of Personality and Social Psychology, 229. } & \text { 55, }\end{array}$ http://dx.doi.org/doi/10.1037/0022-3514.55.2.211

Chappell, D., \& Di Martino, V. (2006). Violence at work (3rd ed.). Geneva: International Labor Office.

Connolly, J., \& Viswesvaran, C. (2000). The role of affectivity in job satisfaction: a meta-analysis. Personality and Individual Differences, 29, 265-281. http://dx.doi.org/10.1016/S0191-8869(99)00192-0

Costello, A., \& Osborne, J. (2005). Best practices in Exploratory Factor analysis: Four Recommendations for getting the most from your data analysis. Practical Assessment, Research \& Evaluation, 10(7).

Cote, S., \& Morgan, L. (2002). A longitudinal analysis of the association between emotion regulation, job satisfaction and intentions to quit. Journal of organizational Behavior, 23, 947-962. http://dx.doi.org/10.1002/job.174

Cummings, L., \& Berger, C. (1976). Organization structure: How does it influence attitudes and performance? Organizational Dynamics, 5(2), 34-49. http://dx.doi.org/10.1016/0090-2616(76)90053-X

Dunham, R. (1979). Job design and redesign. In K. Steven (Ed.), Organizational Behavior (pp. 337-354). Columbus, OH: Grid.

Estrada, C., Isen, A., \& Young, M. (1994). Positive affect influences creative problem solving and reported source of practice satisfaction in physicians. Motivation and Emotion, 18, 285-299. http://dx.doi.org/10.1007/BF02856470 
Fineman, S. (1993). Emotion in Organizations (1st ed.). New Delhi: Sage.

Fisher, C. (1998). A preliminary test of Affective Events Theory. Paper presented at the First Conference on Emotions and Organizational Life. San Diego, CA.

Fisher, C. (2002). Antecedents and consequences of real-time emotional reactions at work. Motivation \& Emotion, 26, 3-30. http://dx.doi.org/10.1023/A:1015190007468

Fisher, C., \& Ashkanasy, N. (2000). The emerging role of emotions in work life: An introduction. Journal of Organizational Behavior, 21, 123-129. http://dx.doi.org/10.1002/(SICI)1099-1379(200003)21:2

Forgas, J. (1999). On feeling good and being rude: Affective influences on language use and request formulations. Journal of Personality and Social Psychology, 76, 928-939. http://dx.doi.org/10.1037/0022-3514.76.6.928

Garg, P., \& Rastogi, R. (2006). New model of job design: Motivating employees' performance. Journal of Management Development, 25(6), 572-587. http://dx.doi.org/10.1108/02621710610670137

George, J. (1990). Personality, affect, and behavior in groups. Journal of Applied Psychology, 75, 107-116. http://dx.doi.org/10.1037/0021-9010.75.2.107

George, M. (1991). State or trait: Effects of positive mood on prosocial behaviors at work. Journal of Applied Psychology, 76(2), 299-307. http://dx.doi.org/10.1037/0021-9010.76.2.299

Gibson, D. (2006). Emotional episodes at work: An experiential exercise in feeling and expressing emotions. Journal of Management Education, 30, 477-500. http://dx.doi.org/10.1177/1052562905282016

Grandey, A., Tam, A., \& Brauberger, A. (2002). Affective States and Traits in the Workplace: Diary and Survey Data from Young Workers. Motivation and Emotion, 26(1), 31-55. http://dx.doi.org/10.1023/A:1015142124306

Hackman, J., \& Oldham, G. (1975). Development of the job diagnostic survey. Journal of Applied Psychology, 60, 159-170. http://dx.doi.org/10.1037/h0076546

Hochschild, A. (1979). Emotion Work, Feeling Rules, and Social Structure. American Journal of Sociology, 85(3), 551-575.

Hochschild, A. (1983). The Managed Heart: The Commercialization of Human Feeling. London: University of California Press.

Isen, A. (2000). Positive affect and decision making. In J. Haviland-Jones (Ed.), Handbook of emotions (pp. 417-435). New York: The Guilford Press.

Jacobs, R. (2001) Using human resource functions to enhance emotional intelligence. In C. Cherniss \& D. Goleman (Eds.), The emotionally intelligent workplace (pp. 159-181). San Francisco, CA: Jossey-Bass.

James, L., \& Tetrick, L. (1986). Confirmatory analytic tests of three causal models relating job perceptions to job satisfaction. Journal of Applied Psychology, 71, 77-82. http://dx.doi.org/10.1037/0021-9010.71.1.77

Jelstad, B. (2005). Job characteristics and its outcomes: A comparative work design study of non-profit and profit organizations. Retrieved from www.polis.no/paper/aarhus05/pjelstad.pdf

Jonge, J., Dormann, C., Janssen, P., Dollard, M., Landeweerd, J., \& Nijhuis, F. (2001). Testing reciprocal relationships between job characteristics and psychological well-being: A cross-lagged structural equation model. Journal of Occupational and Organizational Psychology, 74, 29-46. http://dx.doi.org/10.1348/096317901167217

Judge, T., \& Kammeyer-Mueller, J. (2008). Affect, satisfaction, and performance. In N. Ashkanasy, \& C. Cooper, Research companion to emotion in organizations (pp. 136-151). Cheltenham, UK: Edward Elgar Press.

Judge, T., Erez, A., \& Bono, J. (1998). The power of being positive: The relationship between positive self-concept $\begin{array}{llll}\text { and job } \quad \text { Human } & \text { 167-187. }\end{array}$ http://dx.doi.org/10.1080/08959285.1998.9668030

Judge, T., Locke, E., Durham, C., \& Kluger, A. (1998). Dispositional effects on job and life satisfaction: The role of core evaluations. Journal of Applied Psychology, 83, 17-34. http://dx.doi.org/10.1037/0021-9010.83.1.17

Klinger, E. (1977). Meaning and void: Inner experience and the incentives in people's lives. Minneapolis, MN: University of Minnesota Press.

Klinger, E., Barta, S., \& Maxeiner, M. (1980). Motivational correlates of thought content frequency and

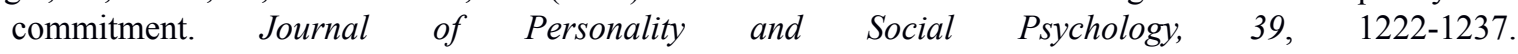


http://dx.doi.org/10.1037/h0077724

LeDoux, J. (1998). Cognition and Emotion: Listen to the Brain. In R. Lane (Ed.), Emotion and Cognitive Neuroscience. New York: Oxford U. Press.

Lee, K., \& Allen, N. (2002). Organizational Citizenship Behavior and Workplace Deviance: The Role of Affect $\begin{array}{lllll}\text { and Cognitions. Journal of Applied Psychology, 87(1), 131-142. } & \end{array}$ http://dx.doi.org/10.1037/0021-010.87.1.131

Li, Y., Ahlstrom, D., \& Ashkanasy, N. (2010). A multilevel model of affect and organizational Commitment. Asia Pacific Journal of Management, 27, 193-213. http://dx.doi.org/10.1007/s10490-010-9193-9

Locke, A. (1976). The nature and causes of job satisfaction. In M. Dunnette (Ed.), Handbook of industrial and organizational psychology (pp. 1297-1343). Chicago: Rand McNally.

McNeely, B., \& Meglino, B. (1994). The role of dispositional and situational antecedents in pro-social organizational behavior: An examination of the intended beneficiaries of pro-social behavior. Journal of Applied Psychology, 79, 836-844. http://dx.doi.org/10.1037/0021-9010.79.6.836

Michael, A. (1998). A handbook of Personnel Management Practice (6th ed.). Kogan Page Limited, London.

Mowday, R., Steers, R., \& Porter, L. (1979). The measurement of organizational commitment. Journal of Vocational Behavior, 14, 224-247. http://dx.doi.org/10.1016/0001-8791(79)90072-1

Nunnally, J. (1978). Psychometric Theory. New York: McGraw-Hill.

Organ, D. (1988). A restatement of the satisfaction- performance hypothesis. Journal of Management, 14, 547-557. http://dx.doi.org/10.1177/014920638801400405

Podsakoff, N., Whiting, S., Podsakoff, P., \& Blume, B. (2009). Individual-and Organizational-Level Consequences of Organizational Citizenship Behaviors: A Meta-Analysis. Journal of Applied Psychology, 94(1), 122-141. http://dx.doi.org/10.1037/a0013079

Podsakoff, P., \& MacKenzie, S. (1997). Impact of organizational citizenship behavior on organizational performance: A review and suggestions for future research. Human Performance, 10, 133-151. http://dx.doi.org/10.1207/s15327043hup1002_5

Renn, R., \& Vandenberg, R. (1995). The critical psychological states: An underrepresented component in job characteristics model research. Journal of Management, 21, 279-303. http://dx.doi.org/10.1177/014920639502100206

Rhoades, L., Eisenberger, R., \& Armeli, S. (2001). Affective commitment to the organization. Journal of Applied Psychology, 86, 825-836. http://dx.doi.org/10.1037/0021-9010.86.5.825

Robinson, S., \& Bennett, R. (1995). A typology of deviant workplace behaviors: A multidimensional scaling study. Academy of Management Journal, 38, 555-752. http://dx.doi.org/10.2307/256693

Saavedra, R., \& Kwun, S. (2000). Affective states in job characteristics theory. Journal of organizational Behavior, 21, 131-146. http://dx.doi.org/10.1002/(SICI)1099-1379(200003)21:2<131::AID-JOB39>3.0.CO;2-Q

Sokoya, K. (2000). Personal predictors of job satisfaction for the public sector managers: implications for management practice and development in a developing company. Journal of Business in Developing Nations, 4(1).

Spector, P., \& Fox, S. (2005). A stressor-emotion model of counterproductive work behavior. In S. Fox, \& P. Spector (Eds.), Counterproductive work behavior: Investigations of actors and targets (pp. 151-174). Washington, DC: APA.

Spector, P., \& Jex, S. (1991). Relations of job characteristics from multiple data sources with employee affect, absence, turnover intentions, and health. Journal of Applied Psychology, 76, 46-53. http://dx.doi.org/10.1037/0021-9010.76.1.46

Spector, P., Fox, S., Penney, L., Bruursema, K., Goh, A., \& Kessler, S. (2006). The dimensionality of counterproductivity: Are all counterproductive behaviors created equal? Journal of Vocational Behavior, 68, 446-460. http://dx.doi.org/10.1016/j.jvb.2005.10.005

Van Dyne, L., Cummings, L., \& McLean Parks, J. (1995). Extra-role behaviors: In pursuit of construct and definitional clarity. In L. Cummings, \& B. Staw (Eds.), Research in organizational behavior (pp. 215-285). Greenwich, CT: JAI Press. 
Weiss, H. (2002). Antecedents of emotional experiences at work. Motivation and Emotion, 26, 1-2. http://dx.doi.org/10.1023/A:1015138223398

Weiss, H., \& Cropanzano, R. (1996). Affective events theory: A theoretical discussion of the structure, causes and consequences of affective experiences at work. In B. Staw \& L. Cummings (Eds.), Research in Organizational Behavior (pp. 1-74). Greenwich, CT: JAI Press.

Williams, L., \& Anderson, S. (1991). Job satisfaction and organizational commitment as predictors of organizational citizenship and in-role behaviors. Journal of Management, 17, 601-617. http://dx.doi.org/10.1177/014920639101700305

Yang, J., \& Diefendorff, J. (2009). The Relations of Daily Counterproductive Workplace Behavior With Emotions, Situational Antecedents, And Personality Moderators: A Diary Study In Hong Kong. Personnel Psychology, 62, 259-295. http://dx.doi.org/10.1111/j.1744-6570.2009.01138.x

Zerbe, W., Härtel, C., \& Ashkanasy, N. (2006). Individual and organizational perspectives on emotion management and display. Oxford, UK: Elsevier Science. http://dx.doi.org/10.1016/S1746-9791(06)02002-5

\section{Copyrights}

Copyright for this article is retained by the author(s), with first publication rights granted to the journal.

This is an open-access article distributed under the terms and conditions of the Creative Commons Attribution license (http://creativecommons.org/licenses/by/3.0/). 